This Journal is available in Telkom University online Journals

Jurnal Manajemen Indonesia

Journal homepage: journals.telkomuniversity.ac.id/ijm

\title{
Determining Customer Relationship Management Strategy With Customer Personality Analysis Using Ontology Model Approach
}

Alya Rysda Ramadhanti ${ }^{1}$, Rafa Syafiq Bastikarana ${ }^{2}$, Andry Alamsyah $^{3}$, Sri Widiyanesti ${ }^{4}$

1,2,3,4 Fakultas Ekonomi dan Bisnis, Universitas Telkom, Bandung, Indonesia

\begin{abstract}
Indonesia is a market with attractive e-commerce growth in the past four years. The tight competition made the company try to find ways to maintain customer loyalty, including making improvements to the Customer Relationship Management (CRM) strategy. The way to establish a good CRM strategy is driven by a good approach from the company to customers. Through the process of understanding customer personality, major companies able to understand their customer behaviour, therefore, companies driven by their marketers can perform product marketing activities that are tailored to the tendency of the customer's personality. This research was conducted to determine the personality of the customer by utilizing data obtained from online reviews of several products using the ontology model approach. Personality is measured based on words and phrases given by customers through their online reviews with the help of the Big Five Personality theory in the classification process. The results of this study indicate that the measurement of personality using an ontology model reconstructed with the n-gram algorithm shows that customers on several products have different personalities. These personalities can be used as a foundation in determining and establishing CRM strategies in order to gain higher customer engagement.
\end{abstract}

Keywords-Customer Relationship Management, Online Review, Ontology Model, Personality Measurement

\begin{abstract}
Abstrak
Indonesia merupakan pasar dengan pertumbuhan e-commerce yang menarik dari tahun ke tahun dalam kurun waktu empat tahun terakhir. Ketatnya persaingan membuat perusahaan mencoba mencari cara dalam mempertahankan loyalitas customer, diantaranya adalah dengan melakukan penyempurnaan penetapan strategi Customer Relationship Management (CRM). Penetapan strategi CRM yang baik didorong dengan pendekatan yang baik oleh perusahaan kepada konsumen. Dengan memahami kepribadian customer, perusahaan dapat mengetahui kecenderungan customer dalam melakukan pembelian barang, sehingga perusahaan dapat melakukan kegiatan pemasaran produk yang disesuaikan dengan kecenderungan kepribadian customer untuk meningkatkan customer engagement. Penelitian kali ini dilakukan untuk mengetahui kepribadian dari customer dengan memanfaatkan data yang diperoleh dari online review beberapa produk menggunakan pendekatan model ontologi. Kepribadian diukur berdasarkan kata dan frasa yang diberikan oleh customer melalui online review dengan bantuan teori Big Five Personality dalam proses klasifikasi. Hasil dari penelitian ini menunjukan bahwa pengukuran kepribadian menggunakan model ontologi yang direkonstruksi dengan algoritma n-gram menunjukan bahwa konsumen yang mengunggah review pada beberapa produk memiliki kepribadian yang berbeda. Kepribadian tersebut dapat dijadikan landasan oleh perusahaan dalam menentukan dan melakukan penetapan strategi CRM untuk membantu perusahaan dalam melakukan pendekatan pada customer.
\end{abstract}

Kata kunci-Customer Relationship Management, Model Ontologi, Online Review, Pengukuran Kepribadian

\section{INTRODUCTION}

The rapid development of social media greatly affects the needs of consumers in conducting personal, interactive and collaborative interactions. Social media provides new methods of communication and 
interaction, not only between consumers but also between consumers and companies (Hollebeek et al. 2014; Sasser et al. 2014). The development of social media also applies to companies to deliver messages regarding their products or services to consumers (Lehmkuhl dan Jung 2013). Social media allows companies to interact with consumers, share information or even get reviews from consumers.

Company involvement in communications with consumers through social media has had a large impact in developing customer relationship management strategies (Malthouse et al. 2013). By actively involving users in interactions through social media, companies can take contingencies to increase customer satisfaction and loyalty (Hollebeek et al. 2014). Through social media, companies have expansive knowledge of consumer information, as well as consumer interaction networks (Reinhold dan Alt 2012). Information about opinions and views related to products, brands, or companies is expected to reveal the needs and experiences of consumers (Reinhold dan Alt 2012). One way for companies in developing interactions to bring information from consumers is to provide online media review (Greenberg, 2010).

The motives of reviews submitted by customers are driven by the personality types that each customer has (Manner \& Lane, 2018). One way for companies and marketers to manage customer relationships to survive in a fairly long period is to approach customers to better understand the customer's personality (Bleier, Harmeling, \& Palmatier, 2018). Manner \& Lane (2018) also added that human personality types can be used to predict their purpose of sharing knowledge, the purpose of using technology, the purpose of using social media, and other online behaviors. A person's personality can be assessed and analyzed scientifically to get results that can help decision making in various aspects, one of which is in determining the CRM strategy (Rothe, 2017).

The importance of understanding consumer personalities attracts researchers from various disciplines trying to find the most appropriate way to assess personality based on textual data obtained from social media activities (Alamsyah, 2018). The most frequently used fashion of conducting research using social media data is the classification method by machine learning (Pratama et al., 2017). This method is applied to find insights within complex data from social media that are delicate to analyze by humans (Liu, Preotiuc-Pietro, Samani, Moghaddam, \& Ungar, 2016). Machine learning has limitations in analyzing incomplete data or having lots of noise. These limitations make machine learning unable to provide precise classification results if the data provided is incomplete or has lots of noise (Liu, Preotiuc-Pietro, Samani, Moghaddam, \& Ungar, 2016).

One way to overcome the limitations possessed by machine learning methods can be overcome by the use of ontology modeling with the help of experts in the field of psychology to assess personality (Alamsyah, 2018). There are several advantages in using ontology modeling techniques, including a means that can facilitate the process of classification of documents and can be an answer to the deficiencies that are owned by the classification process using machine learning (Alamsyah, et al., 2019). The use of ontology modeling techniques has also been widely applied in classification. Ontology modeling techniques are considered as a complement to the current classification algorithm (Zhao, Ichise, Sasaki, Liu, \& Yoshikawa, 2016).

A considerable need for knowledge of the personality and behavior of consumers is the main foundation of this research. This study aims to assess consumer personality based on online review activities using ontology models. Various linguistic features extracted from online reviews within a certain time frame. The ontology model built through reconstruction using the $\mathrm{N}$-gram algorithm is expected to speed up the process of measuring personality and increase the level of accuracy of the results of personality assessments. The personality assessment results obtained can be used by companies as a basis for establishing customer relationship management strategies that are appropriate to the personalities of each consumer.

\section{LITERATURE REVIEW}

\section{A. Customer Relationship Management}

Customer Relationship Management (CRM) is a comprehensive approach to creating, maintaining, and expanding customer relationships (Anderson \& Kerr, 2002, hal. 89). Customer Relationship based on ecommerce systems is used to increase customer satisfaction to increase sales. CRM must be a touching way of doing business in all areas of management. In general, CRM can be classified into 3 types, namely operational CRM, analytic CRM, and collaborative CRM (Berson, Smith, \& Thearling, 2000).

One type of CRM that often utilizes social media is collaborative CRM. Collaborative CRM is a collaborative application service, such as e-mail, personal publishing, digital community (e-community), 
discussion forums and other tools aimed at facilitating interactions between customers and companies. CRM strategies with components as mentioned earlier have the main goal of maximizing customer profits along with maintaining and increasing customer satisfaction (Berson, Smith, \& Thearling, 1999). The most common way to facilitate interaction with consumers is to provide customer reviews (Greenberg, 2010). Reviews left by customers can form digital records that can be used as a basis for knowing the customer's personality (Abbas et al., 2019). By knowing the customer's personality, we can adjust the CRM planning process to the customer's main needs based on his personality (Bleier et al., 2018).

\section{B. Personality dan Personality Measurement}

Personality contains emotional values, attitudes and talents, and is an anchored personal characteristic (Gunter, 2019, hal. 1). Personality symbolizes the development of a person's complete psychological system. Another definition of personality is a consistent pattern of feelings, thoughts, and behavior (Kotler \& Keller, 2016, hal. 185). Personality is a part of psychology whose utilization can vary from industry, consumer, organization, and machine. In industrial psychology, personality helps to classify and select employees. Personality can distinguish one person from another person by using traits. In other words, personality means the response to the same group of stimuli over a long time (Riggio, 2017, hal. 123).

Personality has been endorsed as one of the most indispensable topics in psychological studies (Costa \& McCrae, 1992). Research shows that the results of personality assessments determine many aspects of life, including work performance, social status, academic success, political attitudes, decision-making processes and online behavior (Azucar et al., 2018). The classic approach to measuring personality requires respondents to answer a series of questions to evaluate their behavioral preferences (Azucar et al., 2018). Another approach to measuring personality is through face-to-face interviews (Dwivedula et al., 2016). While self-managed interviews and questionnaires are deliberately more accurate in sophisticated ways, online users may not want to spend a lot of time filling out questionnaires, to personalize their search results or product recommendations (Farnadi et al., 2016). Therefore, to overcome these challenges, researchers use social media data that is spread on the internet, in various ways to analyze data, including machine learning and ontology (Sewwandi et al., 2017).

\section{Big Five Personality Theory}

Big Five Personality according to the personality trait model is built into five factors or dimensions such as Openness, Conscientiousness, Extraversion, Agreeableness, and Neuroticism known as OCEAN (Costa \& McCrae, 1992). The Big Five Personality model uses a lexical hypothesis that groups words or language used in daily life to describe the individual characteristics of others (Ramdhani, 2012). The Big Five Personality Theory is built by examining the basis of personality and analyzing the vocabulary used daily. To understand more about each factor will be explained as follows (Costa \& McCrae, 1992):

1. Openness or usually called openness to experience, refers to individuals who have intellectual curiosity, selfawareness, and independence.

2. Conscientiousness refers to individual planning, maintaining the quality of persistence, and achievementoriented.

3. Extraversion refers to individuals who are involved with the outside world and have the enthusiasm and create positive emotions.

4. Agreeableness refers to individuals who value social harmony or coordination and cooperation, are honest, trustworthy, and optimistic.

5. Neuroticism refers to the assessment of past negative feelings and emotions that are unstable or overreact emotionally.

Previous research used the Big Five Personality theory to assess personality. Distinguishing individuals can be represented by terms that exist in the language used by each individual (John, Robins, \& Pervin, 2008 , hal. 117). In other words, all kinds of words and terms that represent these traits are included as the Big Five Inventory (BFI). The use of BFI can be translated into other languages to suit the culture of the language itself to prevent cross-cultural deviations. BFI itself is still considered too broad to represent personality traits. Therefore, there is a metric called NEO Personality Inventory-Revised (NEO-PI-R) which will make the process of classifying words easier than using BFI (John, Robins, \& Pervin, 2008, hal. 125). Traits and facets of the Big Five Personality theory are shown in Table 1. 
Table 1. Big Five Personality Traits

\begin{tabular}{cr}
\hline Personality Traits & Facets \\
\hline Openness & Fantasy, Aesthetic, Feelings, Actions, Ideas, Values \\
Conscientiousness & Competence, Order, Dutifulness, Achievement Striving, Self-Discipline, Deliberation \\
Extraversion & Warmth, Gregariousness, Assertiveness, Activity Level, Excitement Seeking, Positive Emotions \\
Agreeableness & Trust, Straightforwardness, Compliance, Tendermindedness, Modesty, Altruism \\
Neuroticism & Anxiety, Angry Hostility, Depression, Self- Consciousness, Impulsiveness, Vulnerability \\
\hline
\end{tabular}

Source: Costa \& McCrae, 1992

\section{Personality Measurement Based on Social Media Activity}

Encouraged by the increasing evidence of the relationship between personality and online behavior, researchers have begun to explore the use of digital footprints left by people on social media to take assessments of one's personality (Azucar et al., 2018). Recent studies in this field, build up to have some distinctive research designs. However, several studies differ in terms of the social media platforms they use to get textual data. For example, Park et al. (2015) investigated the feasibility of predicting personality traits based on text features extracted from Facebook status updates using topic modeling techniques. Likewise, Liu et al. (2016) and Qiu et al. (2012) both analyzed the language/text used on Twitter to create predictive models for the Big 5 feature. While Gao et al. (2013), Li et al. (2014) and Wei et al. (2017) identified characteristics of the Big 5 theory taken from Sina Weibo microblog, various combinations of digital footprints (activity vs. activity + language vs. activity + activity + image) used in their analysis.

\section{E. Ontology}

Ontology is a formal depiction about groups of explicit concepts. Ontology classifies vocabulary and taxonomy that models a domain that is defined through objects, concepts, properties and relations (Aspers, 2015). Ontology can also be said as a collection of classes and sub-classes that are interrelated, where existing classes indicate entities from the domain and specific relationships that occur between the entities (Sewwandi, et al., 2017).

Ontology has several forming components, namely 1) Class, is the main component in the formation of ontology. A class can represent a collection of several individuals or components that exist in a concept; 2) Instances, are the most basic things in the formation of ontology, instances can explain the scope discussed in an ontology; 3) Relation, is a relationship that explains the relationship between an instance with another instance or a class with another class (Noy \& McGuinness, 2001).

The development process of ontology has three paradigms: top-down, bottom-up, and a combination paradigm. The top-down paradigm process starts with determining the main class first, then continuing with the instances below it. The bottom-up paradigm starts with looking at existing data, from the smallest part, and then grouped to form a new class. The grouping is carried out continuously until the broader main parameters are found; while the combination paradigm is a paradigm that combines the top-down paradigm and the bottom-up paradigm (Saad \& Shahnita, 2016).

\section{RESEARCH METHODOLOGY}

\section{A. Data Collection}

This study uses User Generated Content (UGC) as the main datasets. UGC is a form of interaction between users through media outlets to carry out all forms of social interaction activities. Some forms of UCG include reviews, tweets, images, videos (Moens et al., 2014). This study uses a data collection method from the media (internet) known as data mining, where data retrieval is done using computers to explore large volumes of data in order to find any patterns (Turban et al., 2015). This study uses an online review dataset of a product to represent the personality of its customers. The author determines several criteria of the data that's been used so that the constructed ontology model has a great accuracy. These criteria are as follows: 
1. Customer reviews are taken from products that have more than 4,000 reviews

2. Customer reviews are taken from products in popular commodity categories

3. Customer reviews taken are the latest reviews of a product

4. Customer reviews have relevance to the product

5. Reviews uploaded by each customer have differences

Criteria are created with the aim of having a quality balance in every customer review obtained. Criteria are made to establish an ontology models in measuring personality, which will be used to measure the personality of the certain products' consumers. This study will utilize different customer's review datasets from three specific products in the same industrial area. Each product will have the same amount of customer review data in order to have the same results. The results of data collection are shown in Table 2.

Table 2. Number of Customer Review Data Retrieval Results

\begin{tabular}{cc}
\hline Product & Number of Review Obtained \\
\hline Product A & 1200 \\
Product B & 1200 \\
Product C & 1200 \\
Total Online Review & 3600 \\
\hline
\end{tabular}

\section{B. Data Pre-processing and Data Filtering}

Pre-processing is a stage of text mining with the aim of preparing text into data that will undergo processing at the further stage. In text mining, raw data that contain information has an arbitrary structure, so the process of converting forms into structured data is needed (Apriliana, Ransi, \& Nangi, 2017). Pre-processing is done with the aim of selecting each word from the document and reducing the possibility of errors in the data processing (Alamsyah, Putra, Fadhilah, \& Nurwiati, 2018). The stages of pre-processing in this study are as follows:

1. Case Folding is the stage of changing all letters of documents / data obtained into lowercase letters.

2. URL Removal and Username Removal Removal and Username Removal is the stage of removing URLs and usernames from documents / data obtained

3. Symbol and Numbering Removing is the stage of deleting symbols or numbers in documents / data obtained

\section{Ontology Model Development}

The construction of the ontology model is intended to classify words and phrases from textual data acquired into traits and facets existed in the Big Five Personality theory. There are two ways to classify linguistic feature data with higher accuracy, i.e. professional judgment or classification using machine learning methods (Jurafsky, 2000). This research proposes an ontology model to classify words and phrases accurately into traits available in the Big Five Personality theory; therefore, this model requires experts' involvement in the development process. The created ontology models along with the data sets used are validated by psychology discipline's experts. The validation process requires experts to validate each keyword in the ontology model that reflects the personality in the Big Five Personality model. Examples of classifying keywords into a personality are shown in Table 3.

Table III. Example of Keyword Making

\begin{tabular}{llll}
\hline Review & Keyword & Facet & $\begin{array}{l}\text { Traits } \\
\text { (Kepribadian) }\end{array}$ \\
\hline $\begin{array}{l}\text { kebetulan lip cream ini milik ibuku } \\
\text { dan aku iseng coba. }\end{array}$ & $\begin{array}{l}\text { kebetulan } \\
\text { iseng_coba }\end{array}$ & $\begin{array}{l}\text { impulsiveness } \\
\text { excitement seeking }\end{array}$ & $\begin{array}{l}\text { neuroticism } \\
\text { extraversion }\end{array}$ \\
\hline
\end{tabular}

In this study, the ontology model is designed using the OWL ontology development language, using protection software with the help of the OWL-DL package. Categories in the ontology model are divided into main categories, sub-categories and individual levels. The main interest categories are the personality traits of the Big Five Personality theory, namely Openness, Conscience, Extraversion, Agreeableness, and Neuroticism. Sub-categories are on the same level as facet personality, which is a sub-feature of the Big Five Personality model. Words and phrases are placed at the lowest level; an example of the structure of the ontology model used in this study shown by the following Figure 1. 


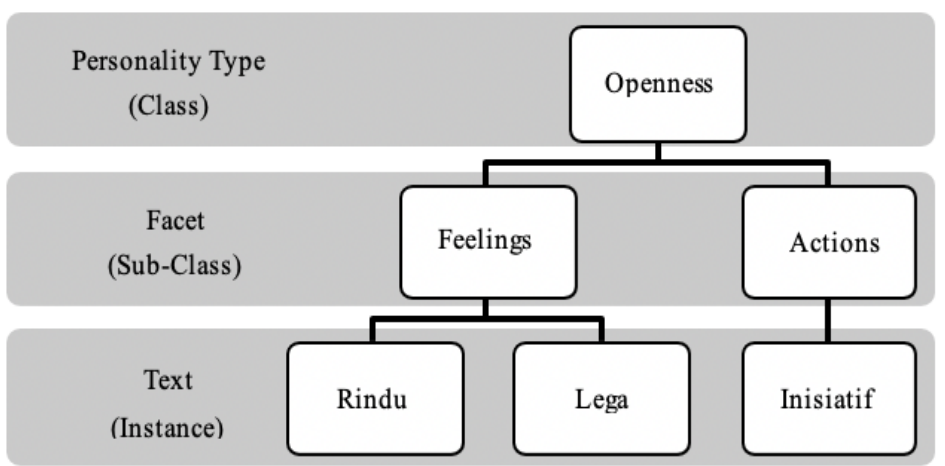

Figure 1. Keyword Classification Paradigm

\section{Personality Measurement Using Ontology Model}

Measurement of personality using ontology model is done by looking at the similarity of words, between words contained in the review with instances existed in the model. If there is at least one word related to the review with the instance in the model created, the review is grouped into the personality class where the instance exists. The measurement is done by looking at the tendency of each word in the sample data online customer review; the higher the frequency of data belonging to a specific class or personality, the greater the value for the personality trait. Figure 2. displays the workflow of the measurements made.

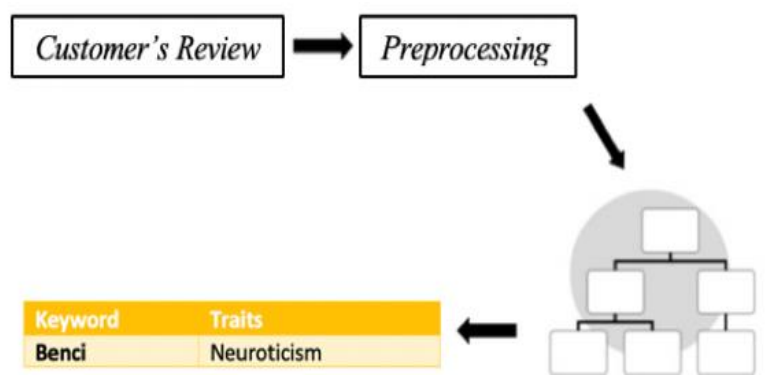

Figure 2. Personality Measurement's Flow Chart

The diagram shown in Figure 2 is a visualization of the measuring personality's process. The diagram shows the flow of personality measurements from collecting customer's review data, pre-processing, building ontology models based on the results of the classification that has been done earlier until the process of measuring personality for the entire sample data used. The whole process is carried out to construct an ontology model that will be reconstructed using an automation algorithm to provide rapid and improved the accuracy of personality measurement results. The automation algorithm is constructed using the n-gram language model with the python programming language. The structure of the personality measurement model algorithm in this study is shown in Table 4.

Our personality measurement model algorithm consists two main functions, they're the looping function and the if function. The looping function for ' $\mathrm{j}$ ' aims to check the input of words or phrases in the ontology model's construction. Then, the looping function for ' $\mathrm{k}$ ' is used to carry out a comparative assessment of the input words or phrases that will be pushed through the process of measuring personality and compared with words or phrases found in the ontology models that have been made. Furthermore, the if algorithm function is used to check words or phrases that have the greatest array words. Types of words or phrases in the n-gram language model can be outlined as unigram (one word), bigram (two words), trigram (three words) and n-gram (n-words). The if function works by detecting words with the greatest n-gram values and discarding words with n-gram values that are less than other words or phrases. 
Table 4. Pseudo-code Algorithm

\begin{tabular}{|c|c|}
\hline Function & Algorithm \\
\hline $\begin{array}{l}\text { Looping for } j \\
\text { function }\end{array}$ & 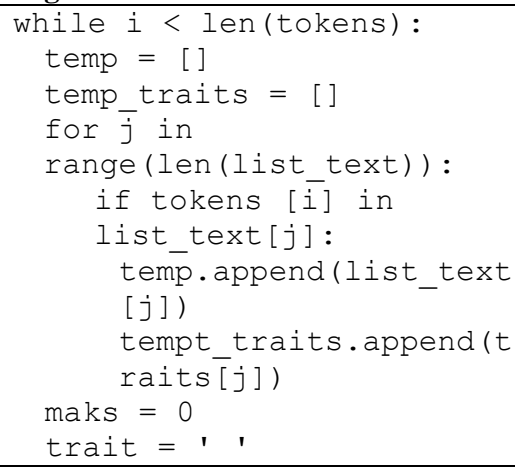 \\
\hline $\begin{array}{l}\text { Looping for } k \\
\text { function }\end{array}$ & 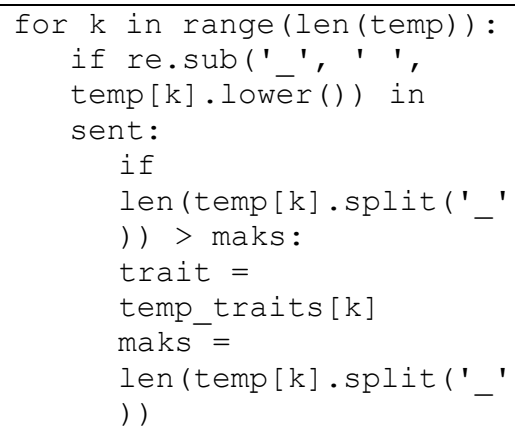 \\
\hline If function & $\begin{array}{l}\text { if maks }>0: \\
\quad \text { list_freq[list_traits.i } \\
\quad \text { ndex(trait)] }+=1 \\
\quad i \quad+=\text { maks } \\
\text { else }: \\
\quad i+=1\end{array}$ \\
\hline
\end{tabular}

\section{RESUlts AND DisCUSSIONS}

\section{A. Ontology Model Construction Result}

Ontology modelling is designed by classifying words and phrases with the help of experts to form a personality dictionary which is then reconstructed using the n-gram algorithm. Examples of the results of word and phrase classification in the personality dictionary can be seen in Table 5 .

Table 5. Examples of Ontology Model Personality Dictionary

\begin{tabular}{|c|c|c|}
\hline Personality & Facet & Keyword Examples \\
\hline \multirow[t]{5}{*}{ Openness } & Fantasy & $\begin{array}{l}\text { Ingin_coba, saya_berharap, mudah_mudahan, } \\
\text { pengen_deh, kapan_kapan, boleh_gak_ya, } \\
\text { pengin_kaya, semoga_nanti, bayangin_aja }\end{array}$ \\
\hline & Aesthethics & $\begin{array}{l}\text { Unik, warnanya_bikin_cerah, cantik_banget, } \\
\text { mempesona }\end{array}$ \\
\hline & Feelings & $\begin{array}{l}\text { Terasa_kering, aku_rasa, aku_suka_banget, } \\
\text { lembut_pas_diaplikasiin, sedih_capur_bahagia }\end{array}$ \\
\hline & Actions & $\begin{array}{l}\text { Perebutan, nyobain, jagain, kubeli, } \\
\text { mendengar, banyak_gaya }\end{array}$ \\
\hline & Ideas & $\begin{array}{l}\text { Usulan, kritik, tanggapan, berfikir, } \\
\text { aku_saranin, testimoni }\end{array}$ \\
\hline
\end{tabular}




\begin{tabular}{|c|c|c|}
\hline & Values & $\begin{array}{l}\text { Bikin_muka_seger, } \\
\text { ngecover_seluruh_bibir, } \\
\text { gak_murahan }\end{array}$ \\
\hline \multirow[t]{6}{*}{ Conscientiousness } & Competence & $\begin{array}{l}\text { Selalu_bisa, layak, kita_bisa, peningkatan, } \\
\text { memahami }\end{array}$ \\
\hline & Order & $\begin{array}{l}\text { Gak_berantakan, rapih, teratur_banget, } \\
\text { suka_banget_rapih }\end{array}$ \\
\hline & Dutifullness & $\begin{array}{l}\text { Ikuti_prosedur, konsisten, teratur, jadwal, } \\
\text { syarat }\end{array}$ \\
\hline & Achievement Striving & $\begin{array}{l}\text { Terpacu_untuk_mulai, tekun, fokus, } \\
\text { kejar_mimpi, berusaha, berjuang }\end{array}$ \\
\hline & Self Discipline & $\begin{array}{l}\text { Mempersiapkan, menempatkan_diri, disiplin, } \\
\text { saya_siap_melayani, bertanggung_jawab }\end{array}$ \\
\hline & Deliberation & $\begin{array}{l}\text { Meskipun, agak_bingung, tetapi, padahal, } \\
\text { entah_kenapa, mempertimbangkan }\end{array}$ \\
\hline \multirow[t]{6}{*}{ Extraversion } & Warmth & $\begin{array}{l}\text { Bareng, salam_hangat, berbaur, } \\
\text { orang_yang_dicintai }\end{array}$ \\
\hline & Gregariousness & $\begin{array}{l}\text { Terkenal, se_terkenal_wardah, banyak_dicari, } \\
\text { lg_booming_banget }\end{array}$ \\
\hline & Assertiveness & $\begin{array}{l}\text { Coba_nih, wajib_coba, jgn_lupa, } \\
\text { jangan_ditiru, perhatiin }\end{array}$ \\
\hline & Activity Level & $\begin{array}{l}\text { Dilayer, beli, pakai, usap, oles, } \\
\text { beli_gara2_promo }\end{array}$ \\
\hline & Excitement-Seeking & $\begin{array}{l}\text { Dicoba_gosok, ini_menarik, iseng_coba, } \\
\text { mau_coba, berani_nyoba }\end{array}$ \\
\hline & Positive Emotions & $\begin{array}{l}\text { Optimis, ceria, bahagia, favorite, } \\
\text { semangat_positif }\end{array}$ \\
\hline \multirow[t]{6}{*}{ Agreeableness } & Trust & $\begin{array}{l}\text { Yakin, gausah_ragu, cinta_mati, tertarik, } \\
\text { pembelian_kedua,gak_nyesel }\end{array}$ \\
\hline & Straightforwardness & $\begin{array}{l}\text { Baru_tau, bener_bgt_ini, emang_beda_tipis, } \\
\text { nyatu_di_bibir, cukup_awet }\end{array}$ \\
\hline & Altruism & $\begin{array}{l}\text { Betah, maklum, ramah, bersedekah, } \\
\text { nyaman_dipake, memuji }\end{array}$ \\
\hline & Compliance & Legowo, puas, gampang_di_blend, awet_juga \\
\hline & Modesty & $\begin{array}{l}\text { Alhamdulillah, bersyukur, maaf, maacih, } \\
\text { berkecukupan }\end{array}$ \\
\hline & Tendermindedness & $\begin{array}{l}\text { Turut_prihatin, Saling_menguatkan, } \\
\text { menebar_kebaikan, mengerti_konsumen }\end{array}$ \\
\hline \multirow[t]{6}{*}{ Neuroticism } & Anxiety & $\begin{array}{l}\text { Ganyaman, ragu, takut_nggak_cocok, } \\
\text { blm_terlalu_berani }\end{array}$ \\
\hline & Hostility & $\begin{array}{l}\text { Brutal, emosi_gua, geblek, nyindir, } \\
\text { maki_maki }\end{array}$ \\
\hline & Depression & $\begin{array}{l}\text { Hancur, sedikit_kecewa, gasesuai_harap } \\
\text { kurang_memuaskan, merasa_dibohongi }\end{array}$ \\
\hline & Self Consciousness & $\begin{array}{l}\text { Bandelnya_aku, berasa_tebel, ga_berani, } \\
\text { gue_yang_salah, ternyata_cocok }\end{array}$ \\
\hline & Impulsiveness & $\begin{array}{l}\text { Langsung_nutup, asal_pilih, lgsg_luntur, } \\
\text { cepet_abis, kehempas }\end{array}$ \\
\hline & Vulnerability & $\begin{array}{l}\text { Gagal, terpuruk, } \quad \text { menyakitkan, } \\
\text { ga_terlalu_bagus, kurang_begitu_suka }\end{array}$ \\
\hline
\end{tabular}

\section{B. Personality Measurement Results based on Ontology Model}

The ontology model that has been designed then reconstructed into an algorithm to facilitate the process of measuring personality. Customer review words and phrases obtained from online reviews are then entered to the 
ontology model algorithm to test the performance of the models that have been made. The results of consumer personality assessments based on the approved online reviews represented in Table 6 below.

Table 6. Personality Measurement Results

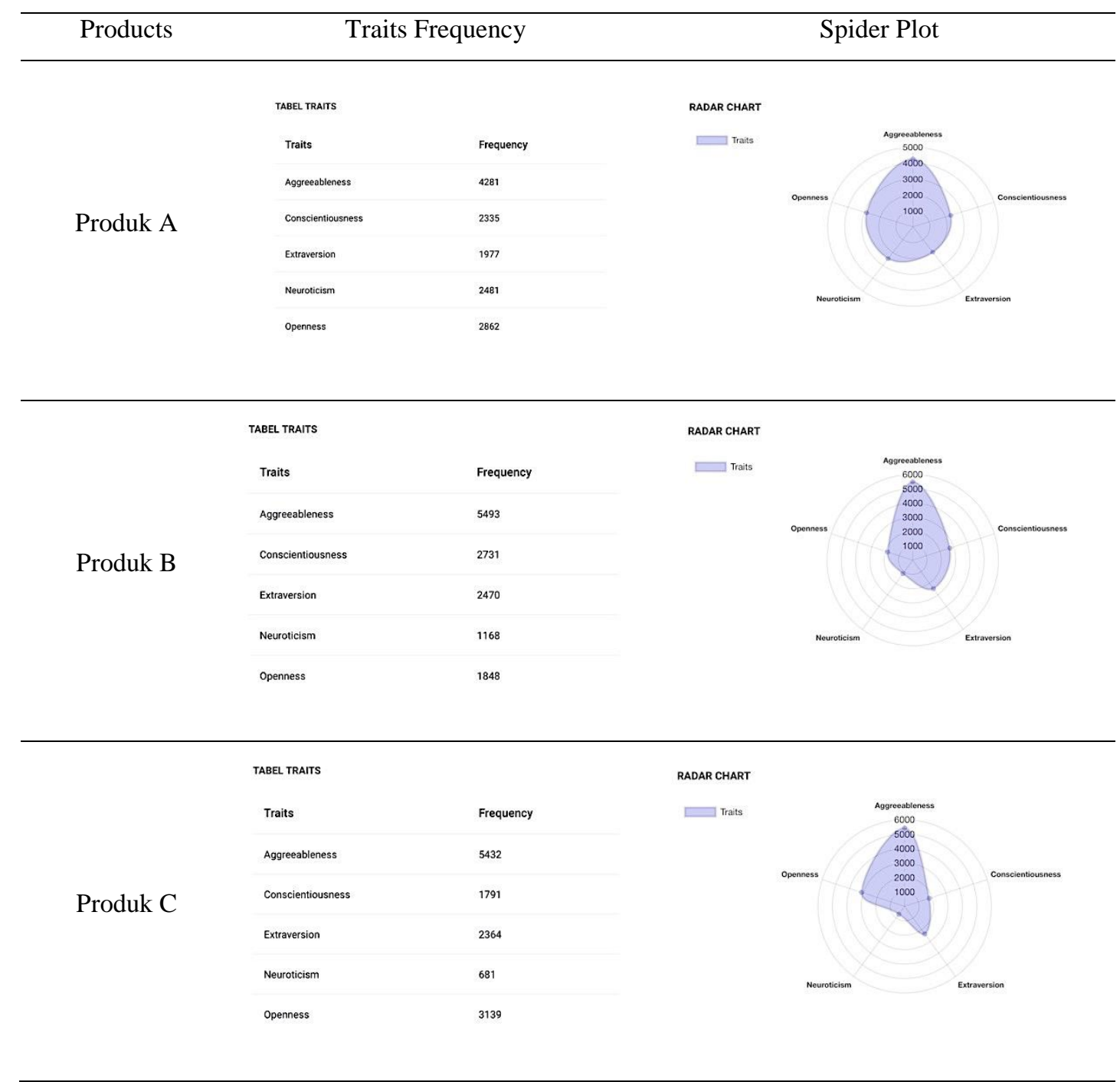

\section{The Analysis of Personality Measurement Results and CRM Strategy Determination}

Based on the results of personality assessments that have been constructed, it is obtained that the groups on the three products have personalities with different percentages from each other. Although the three brands highlight a quite similar main trait, agreeableness, the results of personality assessments show a quite different personality composition. In the context of customer relationship management, a marketer can use the insights gained from the measurement results to improve the effectiveness of the approach to consumers (Srivastava, 2016, hal. 34).

The results showed that consumers of the three products have high agreeableness, openness and extraversion personality. Personality can describe how a person accepts an approach to something, one of which is the approach of a brand (Olson \& Weber, 2004). Someone with a high agreeableness personality tends to be an interpersonal moderator, which means that someone with a high agreeableness value has the motivation to maintain a positive relationship with other individuals (Arthur, Woehr, \& Graziano, 2001). Someone with a dominant agreeableness personality tends to adapt to various social behaviours (Shadish, Cook, \& Campbell, 2002). 
Companies need to determine a CRM strategy that suits the personalities of each of their customers. A theory of establishing a CRM strategy that is commonly used is the 4R CRM theory according to Barnes (2000). 4R CRM theory is a theory that divides the determination of customer relationship management strategies into four elements: Retention, Relationships, Recovery, and References (Barnes, 2000). If it is linked to the results of personality measurements, the CRM approach that is appropriate for customers with high agreeableness personality is the CRM Referrals, by the aim of building interpersonal relationships among potential customers (Srivastava, 2016, hal. 24). A good interpersonal relationship between consumers and prospective customers can support the build of strong word of mouth electronics to increase corporate market support (Srivastava, 2016, hal. 24).

Someone with a high level of Openness personality tends to express their thoughts and feelings through various media; one of them is online review media which is the basis of this research. A person with a high level of Openness personality tends to prefer novelty and consistent originality and has a high level of creativity and imagination (Costa \& McCrae, 1992).

Adjusted to the $4 \mathrm{R}$ approach in the Customer Relationship Management strategy, the ablest approach is a Retention strategy to maintain a good customer lifecycle (Srivastava, 2016, hal. 24). Someone with a high openness personality tends to like something new, by utilizing a retention strategy; companies can maintain the presence of consumers to avoid large numbers of churn. The retention strategy usually begins with the activity of explaining to customers about a new product or service from the company and ended by a contract extension (Barnes, 2000). The implementation of a retention strategy requires good marketing management expertise to execute to maintain consumer presence (Barnes, 2000).

Customers with high extraversion personality tend to make frequent social contacts, and recognition from the social environment (Olson \& Weber, 2004). Someone with a high personality extraversion also tends to have close personal relationships and interdependence (King, 1995), and expect positive things from high interpersonal contact (King \& Broyles, 1997). Someone with a high level of personality extraversion has a clear purpose in life, both in terms of economic, political, and social (Roberts \& Robins, 2000). Therefore, a specific and accurate CRM approach is needed to approach consumers with extraversion personalities.

In carrying out a CRM approach to consumers with a high level of personality extraversion is by improving the inter-relationship between brands and consumers (Bauer, Heinrich, \& Martin, 2007). Based on this, the strategy that can be used is the Relationship CRM strategy (Barnes, 2000). Relationship CRM Strategy seeks for the developing of more intimate relationships between customers and companies, one of them is by providing customer service that constantly interacts with consumers every time (Srivastava, 2016, hal. 24). Consistent interaction between companies and consumers can build consumer loyalty which will create a relationship of interdependence between consumers and companies (Srivastava, 2016, hal. 24).

By understanding the consumer's personality tacitly through the activities carried out on social media, the company can identify the required imminent method to produce an up-sell impact on the CRM strategy. Based on the results of this study, companies are recommended to consider the process of understanding the personality of consumers as one of the standards in making decisions for the determination of CRM strategies. On the other hand, research related to measuring one's personality based on social media activities needs to be deepened and expanded by looking at various applicative sectors supporting the company's business processes in addition to the CRM sector.

\section{CONCLUSION}

The emerging needs of creating a trustworthy company encourage companies to have the right customer relationship management strategy. The challenges in establishing a suitable CRM strategy can be overcome by understanding the personality of the consumer. With the help of understanding personality, companies can determine the CRM strategy that is most suitable for approaching their customers. This study provides a technique to detect consumer personalities based on data obtained from online review results using personality measurements based on ontology models.

This study concludes that the ontology model can be used as an effective personality measurement model, with rapid processing time and less cost consumption. The ontology model reconstructed with the n-gram language model performs exceptional accuracy in terms of measuring the personality of consumers with the 
reviews they upload. Traits and facets obtained from personality measurement results can be used to describe how consumers should get treatment from the company. For example, the CRM approach that is appropriate for groups of customers with high agreeableness personalities is CRM referrals to build interpersonal relationships between customers and potential customers. A good interpersonal relationship can form a strong electronic word of mouth that enlarges the company's market share.

The results of this study recommend the companies to start focusing on detecting the overall personality of their customers since this will be helpful for companies to achieve their goals through the Customer Relationship Management approach. Measurement of personality using the ontology model approach can be used as one method for measuring consumer personalities. With this method, companies can find out the whole personality of their consumer to determine the right CRM strategy and suitable with the personality of the consumer so that the company can increase their customer loyalty.

\section{REFERENCES}

Abbas, J., Aman, J., Nurunnabi, M., \& Bano, S. (2019). The Impact of Social Media on Learning Behavior for Sustainable Education: Evidence. Sustainability, 1-23.

Alamsyah, A., Putra, M. R., Fadhilah, D. D., \& Nurwiati, F. (2018). Ontology Modelling Approach for Personality Measurement Based on Social Media Activity. 2018 6th International Conference on Information and Communication Technology (ICoICT) (hal. 507-513). IEEE.

Alamsyah, A., Rachman, M. F., Hudaya, C. S., Putra, R. P., Rifkyano, A. I., \& Nurwianti, V. (2019). A Progress on the Personality Measurement Model using Ontology based on Social Media Text. International Conference on Information Management and Technology (ICIMTech) (hal. 581-586). Bali: IEEE.

Anderson, K. L., \& Kerr, C. J. (2002). Customer Relationship Management. New York: McGraw-Hill.

Apriliana, Ransi, N., \& Nangi, J. (2017). IMPLEMENTASI TEXT MINING KLASIFIKASI SKRIPSI MENGGUNAKAN METODE NAÏVE BAYES CLASSIFIER. Jurnal semanTIK, 3(2), 187-194.

Arthur, W., Woehr, D. J., \& Graziano, W. G. (2001). Personality testing in employment settings Problems and issues in the application of typical selection practices. MCB University Press, 657-676.

Aspers, P. (2015). Performing ontology. Social Studies of Science, 45, hal. 449-453.

Azucar, D., Marengo, D., \& Settanni, M. (2018). Predicting the Big 5 personality traits from digital footprints on social media: A meta-analysis. Personality and individual differences, 124, 150-159.

Barnes, J. G. (2000). Secrets of Customer Relationship Management: It's All About How You Make Them Feel. New York: McGraw-Hill.

Bauer, H. H., Heinrich, D., \& Martin, I. (2007). How to Create High Emotional Consumer-Brand Relationships? The Causalities of Brand Passion. Australian \& New Zealand Marketing Academy Conference Proceedings, (hal. 2189-2198).

Berson, A., Smith, S., \& Thearling, K. (2000). Building Data Mining Applications for CRM 1st. New York: McGraw-Hill Professional.

Bleier, A., Harmeling, C. M., \& Palmatier, R. W. (2018). Creating Effective Online Customer Experiences. Journal of Marketing, 1-22.

Bleier, A., Harmeling, C. M., \& Palmatier, R. W. (2018). Creating Effective Online Customer Experiences. Journal of Marketing, 1-22.

Costa, P., \& McCrae, R. R. (1992). Neo PI-R professional manual. Psychological Assessment Resources.

Dwivedula, R., Bredillet, C. N., \& Müller, R. (2016). Personality and work motivation as determinants of project success: the mediating role of organisational and professional commitment. International Journal of Management Development, 1(3), 229-245.

Farnadi, G., Sitaraman, G., Sushmita, S., Celli, F., Kosinski, M., Stillwell, D., \& De Cock, M. (2016). Computational personality recognition in social media. User modeling and user-adapted interaction, 26(2-3), 109-142. 
Gao, R., Hao, B., Bai, S., Li, L., Li, A., \& Zhu, T. (2013, October). Improving user profile with personality traits predicted from social media content. In Proceedings of the 7th ACM conference on Recommender systems (pp. 355-358). ACM.

Greenberg, P. (2010). CRM at the Speed of Light, Fourth Edition: Social CRM Strategies, Tools, and Techniques for Engaging Your Customers. New York: The McGraw-Hill Companies.

Gunter, B. (2019). PERSONALITY TRAITS IN ONLINE COMMUNICATION. New York: Routledge.

Hollebeek, L. D., Glynn, M. S., \& Brodie, R. J. (2014). Consumer brand engagement in social media: Conceptualization, scale development and validation. Journal of interactive marketing, 28(2), 149-165.

John, O. P., Robins, R. W., \& Pervin, L. A. (2008). Handbook of Personality. New York: The Guilford Press.

Jurafsky, D. (2000). Speech \& language processing. Pearson Education India.

King, L. A. (1995). Wishes, Motives, Goals, and Personal Memories: Relations of Measures of Human Motivation. Journal of Personality, 985-1007.

King, L. A., \& Broyles, S. J. (1997). Wishes, Gender, Personality, and Well-Being. Journal of Personality, 4976.

Kotler, P., \& Keller, K. L. (2016). Marketing Management. Edinburgh: Pearson.

Lehmkuhl, T., \& Jung, R. (2013). Towards Social CRM-Scoping the concept and guiding research.

Li, L., Li, A., Hao, B., Guan, Z., \& Zhu, T. (2014). Predicting active users' personality based on micro-blogging behaviors. PloS one, 9(1).

Liu, L., Preotiuc-Pietro, Samani, Z., Moghaddam, M. E., \& Ungar, L. H. (2016). Analyzing Personality through Social Media Profile Picture Choice. ICWSM, (hal. 211-220).

Malthouse, E. C., Haenlein, M., Skiera, B., Wege, E., \& Zhang, M. (2013). Managing customer relationships in the social media era: Introducing the social CRM house. Journal of interactive marketing, 27(4), 270280.

Manner, C., \& Lane, W. (2018). Personality Traits as Predictors of Online Customer Review Motivations. The Journal of Social Media in Society, 7(1), 184-210.

Moens, F., Li, J., \& Chua, T. S. (2014). Mining user generated content. Chapman and Hall.

Noy, N., \& McGuinness, D. L. (2001). Ontology development 101. Knowledge Systems Laboratory, Stanford University.

Olson, K. R., \& Weber, D. A. (2004). RELATIONS BETWEEN BIG FIVE TRAITS AND FUNDAMENTAL MOTIVES. (hal. 795-802). Hays: Psychological Reports.

Park, G., Schwartz, H. A., Eichstaedt, Kern, M. L., Kosinski, M., \& Stillwell, D. J. (2015). Automatic Personality Assessment Through Social Media Language. Journal of personality and social psychology, 108(6), 934.

Pratama, B. Y., \& Sarno, R. (2015). Personality classification based on Twitter text using Naive Bayes, KNN and SVM. In 2015 International Conference on Data and Software Engineering (ICoDSE), (hal. 170174). IEEE.

Qiu, L., Lin, H., Ramsay, J., \& Yang, F. (2012). You are what you tweet: Personality expression and perception on Twitter. Journal of Research in Personality, 46(6), 710-718.

Ramdhani, N. (2012). Adaptasi Bahasa dan budaya dari skala kepribadian big five. 39(2), 189-205.

Reinhold, O., \& Alt, R. (2012). Social Customer Relationship Management: State of the Art and Learnings from Current Projects. Bled eConference, 26.

Riggio, R. E. (2017). Introduction to Industrial / Organizational Psychology. New York: Routledge.

Roberts, B. W., \& Robins, R. W. (2000). Broad Dispositions, Broad Aspirations: The Intersection of Personality Traits and Major Life Goals. PERSONALITY AND SOCIAL PSYCHOLOGY BULLETIN, 12841296.

Rothe, J. P. (2017). The Scientific Analysis of Personality . New York: Routledge.

Saad, A., \& Shahnita, S. (2016). The Methodology for Ontology Development in Lesson Plan Domain. Methodology, 7, hal. 4. 
Sasser, S., Kilgour, M., \& Hollebeek, L. D. (2014). Marketing in an interactive world: the evolving nature of communication processes using social media. In K. Lertwachera \& A. Ayanso (Eds.), Harnessing the Power of Social Media and Web Analytics: Techniques, Tools, and Applications (chapter 2) (pp. 2952). New York: IGI Global.

Sewwandi, D., Perera, K., Sandaruwan, S., Lakchani, )., Nugaliyadde, A., \& Thelijjagoda, S. (2017). Linguistic features based personality recognition using social media data. 6th National Conference on Technology and Management (hal. 63-68). IEEE.

Shadish, W. R., Cook, T. D., \& Campbell, D. T. (2002). Experimental and quasi-experimental designs for generalized causal inference. Boston: Houghton Mifflin.

Srivastava, M. (2016). Customer Relationship Management. New Delhi: Vikas Publishing.

Turban, E., King, D., Lee, J. K., Liang, T.-P., \& Turban, D. C. (2015). Electronic Commerce A Managerial and Social Networks Perspective Eighth Edition. London: Springer International Publishing Switzerland.

Wei, H., Zhang, F., Yuan, N. J., Cao, C., Fu, H., Xie, X., ... \& Ma, W. Y. (2017, February). Beyond the words: Predicting user personality from heterogeneous information. In Proceedings of the tenth ACM international conference on web search and data mining (pp. 305-314).

Zhao, L., Ichise, R., Sasaki, Y., Liu, Z., \& Yoshikawa, T. (2016). Fast decision making using ontology-based knowledge base. IEEE Intelligent Vehicles Symposium (IV (hal. 173-178). IEEE. 